\title{
Challenges in the transition to the Education for Sustainable Development paradigm in higher vocational education in Russia
}

\author{
Mikhail Balzannikov', Tatyana Vavilova², Efim Vyshkin ${ }^{3}$ \\ ${ }^{1}$ Samara State University of Architecture and Civil Engineering, \\ ${ }^{2}$ Samara State University of Architecture and Civil Engineering, \\ ${ }^{3}$ Samara State University of Architecture and Civil Engineering
}

\begin{abstract}
The paper focuses on the transition to the education for sustainable development (ESD) paradigm in Russian university education, defining the variety and scope of problems to be solved. A comparative study of the progress in various educational and research fields is presented. The prospects for further solutions are considered.
\end{abstract}

Keywords: Architectural education, curriculum changes, ecological issues, ESD paradigm.

\section{INTRODUCTION}

Last year marked the end of the UN Decade of Education for Sustainable Development (ESD) which concluded at an international UNESCO conference in Nagoya, Japan, from the 10th to 12th November 2014. The conclusions were summarised in a declaration adopted at the conference [1]. This declaration also reiterated the urgency of questions of ESD in the modern world, and called for the inclusion of ESD issues in the list of priority aims for the period beyond 2015.

The development of ESD in the Russian Federation has its own distinctive features [2]. One of them is mainly linguistic, since the essence of the principle of sustainable development is not precisely conveyed in the established Russian translation of the term. 'Ustoychivoe razvitie' solely brings to mind characteristics of a stable process of development [3], whereas in the English term, the dominant idea is of a self-sustaining process, rationally balanced to avoid harmful distortions in any direction. Moreover, it fails to recall another fundamental factor to be found in all manifestos and key documents concerning sustainable development, an orientation towards the future generations who will inherit the world in which we now live.

This comprehensive understanding of sustainable development was formulated as early as 1987 in a UN paper on the environment and development. The emphasis then was on future generations and a concern for their existence, which is easily lost sight of amid the hasty and intensive concentration on the needs of the current generation. Sustainable development may be defined in this way: a strategy of satisfying the demands of the current generation without jeopardising the capacity of future generations to meet their own needs.

Amongst the most important tasks for adherents to the concept of sustainable development the conservation of natural resources necessary for the existence and harmonious development of all peoples (including the conservation of the diversity of these resources and the fairness of their distribution) is primary, along with the preservation of historical, anthropological and cultural (in the broadest terms) heritage and the diversity, development and accumulated spiritual richness and values of mankind over the years of its existence.

Concern over the legacy which will remain for our successors is easily justified with reference to history; the loss of both natural and cultural resources have been constant companions to human development over the ages (see for example [4]). Over time the scale of this loss has reached catastrophic proportions. The twentieth century was characterised not only as a time of exponential population growth, but also of the rapid development of manufacturing and consumption and of globalisation in many other areas of life. Simultaneously, in this epoch of industrialisation the disparity in the pace and character of development in the separate aspects of such growth became more apparent. The clash of technological breakthroughs 
and revolutions lead to man-made ecological crises and severe economic instability, which in their turn provoked social unrest and political fallout.

It became clear that in order to counter the extreme dissonances of development, all of these aspects needed to be somehow harmonised and resolved. The necessity became apparent of re-directing the process of development of modern society along a course which guarded against the risk of arrest, delay or even regress due to crisis or collapse in any one of its aspects. In this way the concept of sustainability, so vital to modern society, was formed.

One of the first (chronologically) aspects of the sustainable development of humanity to emerge concerned the catastrophic condition and development dynamic of ecology, and this may be considered the precursor to the emergence of all paradigms of sustainable development. The UN gathered in 1992 for the Conference on Environment and Development (UNCED), at which two important policy documents were adopted: "Rio Declaration on Environment and Development" and "Agenda 21", in which the basic contours of the concept of sustainable development were set out at a global scale, and a programme for action established.

\section{RESEARCH METHODS}

The fundamental and general principles of sustainable development need to be expressed in concrete terms if they are to be realised in practical daily life and if urgent ecological priorities are to be addressed, such as slowing the rate of deterioration and reducing the level of pollution of the environment [5]. These general aims may become yet more defined when we turn to tasks such as the development of alternative sources of energy [6], the utilisation of industrial and other solid waste or by-products [7], the development of new ecologically sound technologies, the conservation of natural resources, the improvement of urban land use and transport networks, etc.

It is obvious that, one way or another, this problematic should be at the heart of the scientific research and design activity of the universities. It should be noted that these scientific areas were addressed in the research work of many of the departments of Samara State University of Architecture and Civil Engineering (SSUACE) in connection with other technological and social requirements, long before the concept 'sustainable development' appeared. For example, the school of hydro-electrical energy, which is one of the oldest within the walls of the University and has significant accumulated scientific and practical experience, was founded in response to the need for cheaper electrical energy during the industrialisation of the Middle Volga region [8]. This Hydro-technical Institute, as it was then called, was created for research and training specialists in that specific field, but gradually developed into other fields of education and research and today has become a multi-disciplinary university. The approach towards study shifted with the winds of the age.

Hydro-energy, which was once considered of critical importance purely from an economic and technological standpoint, was one of the most significant links in the development of ecological thought, and became the starting point for the development of the theory and practice of renewable sources of energy [8] and the solution of other urgent problems in environment conservation, which were able to make a substantial contribution in such global sustainable development movements as the conservation of resources, the limitation of human impact on the environment [9], preservation of biodiversity and the fight against climate change. The hydro-electrical energy research school has produced several dissertations on the solution of ecological issues (see for example [9]-[12]), and has received patents for a whole series of inventions ([13]-[16]).

In a similar way, other departments of the University are increasingly directing their research activities in accordance with the spirit of the sustainable development paradigm towards the harmonisation of industrial-technological, economic, cultural and historical factors in the development of the country and the regions and the preservation of cultural historical, national and regional identities.

However, the significance of the universities in the investigation of particular issues of sustainable development is not limited to academic research activity. The philosophy of sustainable development prioritises attention on the next generation. Special significance is given to the task of not only conserving the world in all its diversity and functional opportunities, but in educating people to continue this task and seek out ways to further improve these processes. For this reason the recently concluded UN Decade was devoted not only to the actual tasks of sustainable development but also to education in this area. The role of higher education institutions in the promotion of the ideas of sustainable development was particularly highlighted: it was a consistent theme in all of the conferences, seminars and similar events of the Decade.

The need to activate educational technology was reflected in the Nagoya Declaration, which outlines priorities such as youth education (raising the awareness of their responsibility globally and towards the next generations), training of teaching staff for the promotion of the ideas of sustainable development and support for local communities and regional centres.

\section{RESULTS AND DISCUSSION}

Considering that educational and research activities in almost every discipline at SSUACE are being 
drawn into the orbit of the modern concept of sustainable development (industrial-technological, economic, ecological, social etc.), the University has great potential in the development and realisation of methodologies for education in the area of sustainable development. A certain degree of experience in the promotion of principles of education for sustainable development has been accumulated thanks to the fact that the university is host to the Samara Regional Centre of Expertise in Education for Sustainable Development (RCE Samara), which was the first of its kind to be established in Russia. The Centre was founded in 2007 with the official recognition and partnership of the UN University. Along with the centre at Nizhny Novgorod State University of Architecture and Civil Engineering (NNSUACE), it is part of a worldwide network of similar organisations. Owing to the partnership of the two Russian centres, SSUACE and NNSUACE obtained a TEMPUS grant for the development of a Master's programme in innovative project management: "Managers for the Future", the underlying principles of which are education for sustainable development.

Academic disciplines connected with the general and detailed principles of sustainable development are being included in the teaching process in universities in all countries signatory to the Bologna Process (for example in $50 \%$ of higher education institutions in Scandinavia, 96\% in the UK and Sweden) [16]. An interesting case in point is the research and practical application of the philosophy of sustainable development in the education of aspiring architects [17]. The issue of the responsibility of architects and town-planners in the transformation of our planet was raised at a high level at the UN Department of Economic and Social Affairs in 2011. Two basic approaches to education for sustainable development were defined: general and professional. The evaluation of perspectives for the development of the professional approach showed that a decisive factor would be the development of leaders who were ecologically and socially responsible and concerned with ecological and social issues. The leading role of the schools of architecture and town-planning in the formation of a sustainable architectural environment was underlined [18].

The process of introducing the technology of sustainable development into architectural education is growing on different continents. In 2011 four European universities from Spain, The Netherlands, Portugal and the Czech Republic formed a partnership under the International Initiative for a Sustainable Built Environment (iiSBE) to devise the International Masters on Sustainable Building (IMoSB), which was proposed to the European Commission [19].

The teaching of students in the Faculty of Architecture in SSUACE is in accordance with national educational standards and substantially meets them. An extensive revision of course programmes and teaching methodology is being undertaken in the context of sustainable development, with greater attention being given to ecological and social questions. Part of the lecture course in Ecology for Architecture at Bachelor's level is given over to the concept of sustainable development, and many urgent issues in environment conservation are addressed within the frameworks "Individual - society" and “Society - natural environment".

The ability to take into consideration local ecological and social factors is an important step towards professional competency. Both issues are examined from two positions: on the one hand the localisation and neutralisation of negative phenomena, and on the other, the encouragement and widening of positive trends. This theoretical course helps future architects to apply their knowledge in their coursework and final projects. Attention is particularly given to conservation of resources, considering how architectural and urban planning solutions can be developed which minimise negative effects on the ecosystem, and support the relative ecological balance.

Social issues are touched upon with the aid of teaching technologies, and students are expected to take account of particular conditions such as demographics, the economic status of potential clients and the necessity to adopt a tolerant approach [20].

The most interesting design ideas are reflected in the subjects of coursework and final diploma projects which go beyond the bounds of traditional design, for example: “Techno-park in a disused mine", "Residential building designed to 'green' standards", "Redevelopment of former industrial zones", "Shelter for the homeless", "Tolerant space” and others. In addition, one of the most effective means of provoking students to consider ideas of sustainable development is to encourage participation in related competitions, festivals and olympiads.

The University's architecture faculty is currently developing an integrated methodology which brings together both fundamental and inter-disciplinary (ecological and sociological) programmes. This approach facilitates the main pedagogical task - the formation of general cultural and professional competency in aspiring architects, based on the integration and optimal balance of scientific knowledge in different fields.

\section{CONCLUSION}

There is significant potential for the continued development and application of the principles of education for sustainable development in the modern world. UNESCO has called for concrete investment in the realisation of the global action programme, and interested parties in 80 countries have responded, 
taking upon themselves the duties in the above-cited declaration [1].

\section{ACKNOWLEDGMENTS}

The authors would like to express their gratitude to $\mathrm{S}$. C. Buss (MA Cantab, DipArch, ARB) for assistance in producing the English version of the text and valuable advice on the issues addressed.

\section{REFERENCES}

[1] UNESCO, "Aichi-Nagoya Declaration on Education for Sustainable Development", 2014. [Online]. Available: http:// http://www.unesco.org/new/fileadmin/MULTIMEDIA/HQ/E RI/pdf/Aichi-Nagoya_Declaration_EN.pdf. [Accessed: January, 15, 2015].

[2] E. G. Vyshkin, "Higher Education for Sustainable Development in Russia, Ukraine and Kyrgyzstan" in Higher Education for Sustainable Development in Central and Eastern Europe, Maik Adomssene\&Insa. Otte (Eds), Waldkirchen:VAS, 2013 pp. 33-39.

[3] E. G. Vyshkin, "Trends in Education for Sustainable Development in Some Former Soviet Countries" in Vide. Tehnologija. Resursi:9. Starptautiskas zinatniski konferences materiali, 2013 gada. 20.-22. Junijs.1. sejums., , pp.246-249

[4] M. I. Balzannikov, N. G. Chumachenko, A. V. Vinogradov, "Ekologicheskaya kultura Samarskogo regiona," Trudy Samarskogo regionalnogo otdeleniya, Edition 1, 2008.

[5] M. I. Balzannikov, T. Ya. Vavilova, Entries: "Okhrana okruzhayushchey sredy, Ustoychevoe razvitie, Bezopasnost zhiznedeyatelnosti,” Terminologichekiy slovar, 2005.

[6] M. I. Balzannikov, S. V. Evdokimov, Yu. M. Galitskova, "Razvitie vozobnovlyaemoy energetiki - vazhniy vklad v obespechenie zashchity okruzhayushchey sredy," Promyshlennoe i grazhdanskoe stoitelstvo, Vol. 3, pp. 16-19, 2014.

[7] Yu. M. Galitskova, "Sovershenstvovanie metodov zashchity gorodskikh territoriy ot negativnogo vozdeystviya neobustroennykh svalok stroitelnykh otkhodov," Vestnik SGASU, Vol.1, pp. 106-110, 2011.

[8] M. I. Balzannikov and V. A. Shabanov, Razvitie obrazovaniya $i$ nauchnikh issledovaniy $v$ oblasti gidrotekhnicheskogo stroitelsva, Samara: Samarskiy gosud. arkhit.-stroit. un-t, 2004.

[9] S. V. Evdokimov, "Konsentratory potoka vetrovykh energoustanovok i obosnovanie ikh parametrov," Candidate of Technical Sciences Dissertation precis, St Petersburg State Polytechnical University, St Petersburg, Russia, 2004.
[10] A. A. Mikhasek, "Tekhnologiya soznaniya protivofiltratsionnogo ustroystva v plotline iz krupnoporistogo betona," Candidate of Technical Sciences Dissertation precis, Ufa State Oil Technical University, Ufa, Russia, 2006.

[11] V. A. Seliverstov, "Metodika obosnovaniya parametrov vodopriemno-vodovypusknykh ustroystv gidroenergeticheskikh ustanovok," Candidate of Technical Sciences Dissertation precis, St Petersburg State Polytechnical University, St Petersburg, Russia, 2010.

[12] M. V. Rodionov, "Gruntovye perelivnye plotiny s nizovym otkosom, sformirovannym geosinteticheckimi obolochkami," Candidate of Technical Sciences Dissertation precis, Samara State University of Architecture and Civil Engineering, Samara, Russia, 2012.

[13] M. I. Balzannikov and A. A. Bolotova, "Sposob zashchity vodnogo obekta ot zagryazneniya [A method of protecting water from contamination] // RF Patent 2441963. 2012. Bull. Number 4

[14] M. I. Balzannikov, V. A. Shabanov and Yu. M. Galitskova, "Sposob zashchity beregovogo otkosa ot razrusheniya [A method of protecting a bank slope from destruction] // RF Patent 2237129. 2004. Bull. Number 27.

[15] M. I. Balzannikov and A. A. Bolotova, "Sposob zashchity vodoema ot zagryazneniya [Way to protect the water body from pollution] // RF Patent 2392375. 2010. Bull. Number 17.

[16] S. A. Stepanov, "Ekologicheskoe obrazovanie dlya ustoychivogo razvitiya kak vazhnoe napravlenie modernizatsii vysshey shkoly Rossii," Pedegogical Doctorate dissertation precis, university? Moscow, Russia, 2011.

[17] T. Ya. Vavilova, "Paralleli ustoychivogo razvitiya sredyzhiznedeyatelnosti: nauka - vysshee obrazovanie," Vestnik MGSU, Vol. 1, pp. 312-315, 2010.

[18] United Nations Department of Economic and Social Affairs, Economic and Social Council High-Level Segment: Special Policy Dialogue "Education for Sustainable Development" DATE, [Online], Available: http://www.un.org/en/ecosoc/ julyhls/pdf11/education_for_sustainable_developmentconcept_note.pdf, [Accessed: DATE].

[19] iiSBE "Four European Universities Submit Their Proposal for an International Masters in Sustainable Building," Dec. 5, 2011. [Online]. Available: http://www.iisbe.org/node/94, [Accessed: DATE].

[20] T. Ya. Vavilova, "Resursy ustoychivogo razvitiya: arkhitekturno-tipologicheskoe mnogoobrazie infrastruktury sotsialnoy pomoshchi i zashchity," Architecture and Modern Information Technologies, Vol. 3, 2014, [Online] Available: http://www.marhi.ru/AMIT/2014/3kvart14/vavilova/abstract.p hp. [Accessed: DATE]. 